\title{
PUSAT REHABILITASI KAUM MILENIAL DEPRESI DI JAGAKARSA
}

\author{
Aghnia Lovita Tedjamulja ${ }^{1)}$, Andi Surya Kurnia ${ }^{2)}$ \\ 1)Program Studi S1 Arsitektur, Fakultas Teknik, Universitas Tarumanagara, aghnia.It@gmail.com \\ 2)Program Studi S1 Arsitektur, Fakultas Teknik, Universitas Tarumanagara, andik@ft.untar.ac.id
}

\begin{abstract}
Abstrak
Milenial merupakan generasi yang sangat rentan terkena gangguan kecemasan dan depresi dimana bila tidak segera ditangani akan berdampak serius (skizofrenia hingga bunuh diri). Tetapi, banyak penderita depresi ringan atau sedang yang tidak mau langsung berobat dikarenakan kurangnya pemahaman terhadap depresi sehingga munculnya stigma negatif. Banyaknya asumsi dimana depresi dianggap "gila" sehingga penderita tidak mencari pertolongan, menutup diri, dan menyangkal. Bersamaan dengan itu juga, kurangnya fasilitas dan perhatian serius terhadap masalah kesehatan mental (depresi) yang ada di Indonesia. Beberapa rumah sakit jiwa di Indonesia bahkan tidak layak untuk digunakan sebagai tempat pemulihan. Sedangkan dilihat dari sisi psikologis, faktor lingkungan memiliki peran besar dalam proses penyembuhan. Maka dari itu, dibutuhkannya wadah yang memberikan support kepada masyarakat akan kesehatan mentalnya dan mewujudkan lingkungan yang nyaman untuk penderita gangguan mental dalam berobat. Serta meningkatkan kesadaran masyarakat dan memperbaiki stigma terhadap gangguan mental sehingga mendukung terjadinya ikatan sosial yang kuat dan nyaman antara masyarakat dan penderita depresi. Dengan menggunakan metode healing environment, maka Pusat Rehabilitasi Kaum Depresi bertujuan untuk menyikapi semua masalah tersebut dimana pasien mendapatkan berbagai fasilitas kesehatan yang sesuai dibutuhkan dan pengenalan lebih luas mengenai depresi kepada masyarakat sehingga memperbaiki stigma yang sudah tertanam sejak lama.
\end{abstract}

Kata kunci: depresi; rehabilitasi; stigma

\begin{abstract}
Millenials are this generation's young adults who are very vulnerable to an anxiety and depression, which if this disorder no immediately treated, it would impact to psychiatric disorders (schizophrenia and even suicide). However, many mild - depressed people doesn't want to seek treatment immediately because lack of knowledge about depression so there's negative stigma. There are many assumptions where depression is considered "crazy" so which then that patients don't seek any help, close themselves, and deny. In fact, a few mental hospital in Indonesia doesn't even meet the proper standards to be called a recovery center. But, seeing from the side of psychology, environment factor has a huge role in recovery process. Therefore, there is a need for a vessel of support for those people who need help on mental health and realizing a comfortable environment for those who are recovering. And improving the perspective of people on the negative stigma about mental disorder and supporting the realization of a strong, comfortable social relation between people and depression sufferers. By using healing environment method, Sanctuary for Depression aims to respond toward all problems which patients acquire a various of health facilities which are needed accordingly and a broader knowledge about depression, so that the negative stigma which has been planted for a long time could be corrected.
\end{abstract}

Keywords: depression; rehabilitation; stigma 


\section{PENDAHULUAN}

Menurut Solomon (2009), generasi milenial merupakan generasi yang paling mencolok karena terkenal dengan keragamannya. Generasi yang paling tinggi tingkat pendidikannya, perkembangan teknologi yang cepat, peka terhadap perubahan, peningkatan akan pengakuan diri (self-esteem), memiliki ekspektasi yang tinggi terhadap diri mereka sendiri dan orang lain, dan masih banyak lagi. Akan tetapi, generasi ini paling banyak terkena dampak psikologis, yaitu depresi dan kecemasan. Hal tersebut terjadi akibat seiring dengan perkembangan zaman, muncullah berbagai permasalahan lainnya yang dapat mempengaruhi mental seperti kehidupan yang monoton serta tingginya tingkat mobilitas saat ini. Tidak hanya dari kedua hal tersebut saja, tetapi terdapatnya beberapa faktor kehidupan sehari-hari lainnya yang dapat memicu stres baik dalam faktor lingkungan kantor, media sosial, perundungan, obat-obatan, dan masih banyak lagi.

Stres dapat berkembang menjadi gejala yang lebih akut, yaitu depresi. Depresi terbagi menjadi 3 tahap, yaitu: ringan, sedang, dan berat. Bila depresi ringan atau sedang tidak segera ditangani, maka akan berdampak serius dimana dapat merujuk ke gangguan kejiwaan (skizofrenia bahkan sampai bunuh diri). Depresi tidak dapat diobati dalam jangka pendek, tetapi membutuhkan bantuan layanan psikologi. Banyak sekali penderita depresi yang memiliki ciri-ciri dengan menarik diri dari lingkungan, menyendiri, merenung, merasa tidak berharga, dan sebagainya. Tetapi, sering sekali penderita depresi ringan atau sedang tidak langsung berobat. Hal ini dikarenakan kurangnya pemahaman terhadap depresi sehingga munculnya stigma negatif terhadap depresi baik dari sudut pandang masyarakat maupun penderita. Banyaknya asumsi dimana seseorang yang menderita depresi dianggap "gila" sehingga mereka yang seharusnya membutuhkan pertolongan menjadi menutup diri dan menyangkal dirinya sendiri.

Depresi tidak boleh dianggap remeh karena penderita depresi atau gangguan jiwa terus meningkat setiap tahunnya. Berdasarkan data Riskesdas 2013 yang telah dikombinasi dengan data rutin dari Pusdatin Kemenkes, gejala depresi dan kecemasan sudah diidap orang Indonesia sejak usia 15 tahun. Persentase depresi mencapai $6 \%$ atau sekitar 14 juta orang dan hampir 1 orang melakukan bunuh diri setiap harinya akibat depresi.

Seseorang yang mengalami depresi merasa tidak ada jalan keluar lain selain mengakhiri hidupnya sehingga depresi merupakan faktor utama bunuh diri. Depresi-depresi ringan atau sedang sebaiknya segera ditangani. Akan tetapi, banyak penderita yang tidak mencari bantuan kesehatan terutama generasi milenial akibat adanya stigma negatif. Generasi $Y$ yang menderita depresi merasa minder dan malu bila berobat karena generasi tersebut memiliki self-esteem yang tinggi.

Bersamaan dengan itu juga, kurangnya fasilitas dan perhatian serius terhadap masalah kesehatan mental (depresi) yang ada di Indonesia sehingga sering terjadinya pemahaman yang salah akan cara pengobatan depresi. Tempat rehabilitasi di Indonesia masih berpusat kepada rumah sakit jiwa dimana tempat tersebut merupakan tempat rehabilitasi untuk depresi berat. Sedangkan cara pengobatan depresi ringan dan depresi berat sangat berbeda dan tidak boleh disamakan. Banyaknya anggapan yang hanya tertuju pada faktor mediknya saja dimana penderita hanya diberikan obat antidepresan. Sedangkan, faktor lingkungan memiliki peran besar dalam proses penyembuhan.

Maka dari itu, dibutuhkannya wadah yang dapat memberikan support kepada masyarakat akan kesehatan mentalnya dan mewujudkan lingkungan yang nyaman untuk penderita gangguan mental dalam berobat. Pengguna proyek ditujukan untuk penderita depresi ringan dan sedang dimana kurangnya fasilitas kesehatan untuk penderita depresi ringan dan sedang di Jakarta serta memberikan pengenalan lebih luas mengenai depresi untuk meningkatkan kesadaran masyarakat dan memperbaiki stigma terhadap gangguan mental sehingga mendukung terjadinya ikatan sosial yang kuat dan nyaman antara masyarakat dan penderita. 


\section{KAJIAN LITERATUR}

\section{Depresi}

Depresi merupakan satu masa terganggunya fungsi manusia yang berkaitan dengan alam perasaan yang sedih dan gejala penyertanya, termasuk perubahan pola tidur dan nafsu makan, psikomotor, konsentrasi, anhedonia, kelelahan, rasa putus asa dan tidak berdaya, serta bunuh diri (Kaplan, 2010). Menurut Rosenvald, Oei, dan Schmidt (2007) menjelaskan depresi sebagai munculnya perubahan dalam diri individu dalam segi suasana hati (merasa tidak berharga), tingkah laku (mudah marah atau menarik diri dari interaksi dengan orang), fungsi diri (sulit berpikir dan konsentrasi), dan kondisi fisik (sulit tidur atau terlalu banyak tidur), serta perubahan berat badan. Maka dapat disimpulkan pengertian depresi adalah suatu keadaan dimana individu mengalami simptom-simptom perasaan sedih, tertekan, kesepian, berkurang nafsu makan, membutuhkan usaha lebih besar dalam melakukan sesuatu, kesulitan tidur, kesulitan untuk memulai mengerjakan sesuatu, merasa tidak bersahabat, dan merasa tidak disukai orang lain.

\section{Jenis-jenis Depresi}

Menurut American Psychiatric Association (2000) dan Rosenvald, Oei, \& Schmidt (2007), berdasarkan tingkat penyakitnya, depresi dibagi menjadi:

\section{- Mild depression/minor depression dan dysthymic disorder}

Pada depresi ringan, mood yang rendah datang dan pergi dan penyakitnya datang setelah kejadian stressfull yang spesifik. Individu akan merasa cemas dan juga tidak bersemangat. Bentuk depresi yang kurang parah disebut distimia (dystymic disorder). Depresi ini menimbulkan gangguan minor depression ringan dalam jangka waktu yang lama sehingga seseorang tidak dapat bekerja optimal. Gejala depresi ringan ada gangguan distimia dirasakan minimal jangka waktu dua tahun.

\section{- Moderate depression}

Pada depresi sedang, mood yang rendah berlangsung terus dan individu mengalami simptom fisik walaupun berbeda-beda tiap individu. Perubahan gaya hidup saja tidak cukup dan bantuan diperlukan untuk mengatasinya.

\section{- Severe depression/major depression}

Depresi berat adalah penyakit tingkat depresinya parah. Individu mengalami gangguan kemampuan untuk bekerja, tidur, makan, dan menikmati hal yang menyenangkan dan penting untuk mendapatkan bantuan medis secepat mungkin.

\section{Rehabilitasi}

Rehabilitasi adalah segala tindakan fisik, penyesuaian psikososial, dan latihan vokasional sebagai usaha untuk memperoleh fungsi dan penyesuaian diri yang optimal serta mempersiapkan klien secara fisik, mental, sosial, dan vokasional untuk suatu kehidupan penuh sesuai dengan kemampuannya (Nasution, 2006). Sebuah tempat rehabilitasi mental harus dibangun dengan konsep recovery (pemulihan) dimana penekanan yang diterapkan untuk memaksimalkan harapan, makna diri, dan potensi individual. Prinsip dasar dalam pendekatan desain harus berdasarkan recovery-oriented dan evidence-based design paradigm, dikarenakan lingkungan tempat perawatan dapat memberikan pengaruh signifikan dalam proses pemulihan.

\section{Psikologi Arsitektur}

Salah satu bagian dari Psikologi Arsitektur adalah Arsitektur Perilaku. Menurut Gifford (2007), Arsitektur Perilaku berfokus pada hubungan antara perilaku manusia dengan lingkungan binaannya yang terdiri dari tiga aspek, yaitu privasi, kenyamanan, dan keamanan. 


\section{Privasi}

Penataan massa, ruang, dan sirkulasi akan mempengaruhi privasi penderita (Laurens, 2004). Secara tidak langsung, privasi akan memberikan perasaan aman dan nyaman.

\section{Kenyamanan}

Perilaku penderita sangat dipengaruhi oleh kenyamanan dalam suatu bangunan maupun ruangan. Dalam hal ini, kenyamanan yang dimaksud meliputi: penghawaan, pencahayaan, aroma, dan suara.

\section{- Penghawaan}

Suhu dan polusi udara dapat menimbulkan dua efek, yaitu efek kesehatan dan efek perilaku (Holahan, 1982). Udara yang bersih dan sedikitnya polusi udara menjadi salah satu poin untuk pemilihan lokasi.

\section{- Pencahayaan}

Pengaturan intensitas cahaya dalam ruangan dapat mempengaruhi kondisi mental penderita. Intensitas cahaya dapat diatur dengan mereduksi cahaya dengan cara dipantulkan dan diberi sekat untuk memfilter cahaya.

\section{- Aroma}

Indera penciuman manusia mempunyai hubungan langsung yang lebih kuat terhadap memori dan emosi daripada panca indera yang lain sehingga mampu mempengaruhi kondisi kejiwaan seseorang. Aroma yang menyenangkan akan memberikan efek positif bagi tubuh, seperti mampu menurunkan tekanan darah dan detak jantung, sedangkan aroma yang menyengat dan tidak menyenangkan akan menimbulkan kegelisahan.

\section{- Kebisingan}

Kebisingan merupakan salah satu pemicu dari perilaku menyimpang penderita gangguan jiwa. Hal ini terjadi karena suara yang tidak menyenangkan atau suara yang ramai membuat otak seseorang terus bekerja tanpa istirahat (Feriadi dan Frick, 2008).

\section{Keamanan}

Desain yang aman didapat dari penggunaan interior, material, bentuk, dan tekstur yang tidak mencelakai penderita di dalam bangunan maupun lingkungan sekitarnya (Alread dan Leslie, 2007).

\section{METODE}

Metode yang digunakan pada proyek ini adalah pendekatan Healing Environment. Menurut Knecht (2010), healing environment adalah pengaturan fisik dan dukungan budaya yang memelihara fisik, intelektual, sosial, dan kesejahteraan spiritual pasien, keluarga, dan staf serta membantu mereka mengatasi stres terhadap penyakit dan rawat inap. Healing Environment merupakan sebuah lingkungan yang dirancang untuk menciptakan keharmonisan antara pikiran, tubuh, dan jiwa. Dalam penerapan healing environment sangatlah diharuskan untuk menjaga dari unsur psikologis pengguna, diantaranya adalah; alam, indera, dan psikologi. Sehingga healing environment dapat membantu pemulihan pasien, mengurangi rasa sakit, dan depresi atau stres.

\section{DISKUSI DAN HASIL}

\section{Analisis Program Kegiatan}

Berdasarkan hasil tinjauan mengenai depresi dan cara menurunkan depresi melalui rehabilitasi, maka terbentuklah program kegiatan yang mendukung proses penyembuhan depresi. Program kegiatan yang ada di rancangan ini terbagi menjadi 2 (dua) zona, yaitu edukasi dan rehabilitasi. 


\section{Zona Edukasi}

Zona edukasi digunakan untuk pengenalan lebih luas mengenai depresi kepada masyarakat. Program ruang yang berada pada zona ini adalah:

\section{- Galeri}

Galeri ini memberikan pengenalan mengenai tahapan depresi dimana dapat memberikan meningkatkan kesadaran masyarakat akan gangguan mental. Tidak hanya itu, galeri ini menampung karya-karya penderita yang mengikuti rehabilitasi dengan metode art therapy dimana penderita dapat mengekspresikan apa yang mereka rasakan melalui art material.

\section{- Ruang Mimpi}

Masyarakat dipertemukan kembali dengan mimpi awalnya. Dengan menggunakan teknologi, diputarkan kembali impian dan tujuan utama hidup setiap orang yang terlupakan.

\section{Zona Rehabilitasi}

Zona rehabilitasi digunakan untuk tempat penderita mendapatkan pengobatan sehingga zona tersebut memiliki tingkat privasi yang lebih tinggi.

\section{- Ruang Konseling}

Konseling berfokus pada optimalisasi kesanggupan kognitif dan menumbuhkan energi psikis untuk mengantisipasi dan mengatasi stres dan depresi dengan konstruktif dan sehat. Konseling juga dapat digunakan untuk membaca ulang pikiran penderita dan menolong penderita mengatasi permasalahan dengan sehat serta menambahkan kepercayaan diri. Pada setiap ruang konseling, diterapkan terapi aromatik dimana ditanami berbagai jenis bunga yang dapat meredakan stres.

\section{- Ruang Terapi}

Ruang terapi yang digunakan adalah ruang terapi seni dimana penderita menggambarkan apa yang mereka rasakan. Dinding yang berada pada ruang terapi seni dapat digunakan juga sebagai media untuk menggambar. Diberikan kebebasan kepada penderita untuk mencurahkan apa yang dirasakan.

- Ruang Meditasi

Meditasi merupakan salah satu cara untuk relaksasi dengan memfokuskan pikiran pada ritme pernafasan dan menjaga postur tubuh sehingga dapat menenangkan pikiran.

Diantara 2 (dua) zona tersebut, terdapatnya ruang komunal yang dipakai sebagai meeting point dimana tidak adanya pembatas antara penderita dan masyarakat sehingga dapat bersosialisasi, berinteraksi, atau sharing baik secara langsung maupun tidak langsung. Terdapatnya juga ruang baca dan ruang workshop dimana masyarakat dan penderita bekerja sama dan mencari informasi dimana dapat memberikan pengenalan akan gangguan mental lebih dalam baik dalam sisi masyarakat maupun penderita.

\section{Analisis Lokasi}

Berdasarkan tujuan proyek untuk meningkatkan kesadaran masyarakat terhadap depresi, lokasi proyek sebaiknya berada di area yang memiliki intensitas aktivitas yang tinggi. Jakarta merupakan kota yang memiliki aktivitas tertinggi dan golongan masyarakat yang luas. Maka, lokasi proyek berada di Jakarta dan Jakarta Selatan merupakan lokasi yang masih memenuhi kriteria untuk merancang proyek ini.

\section{Kriteria pemilihan tapak:}

a. Dekat dengan rumah sakit atau pusat pelayanan kesehatan lainnya

b. Berada pada lingkungan yang tidak terlalu padat kendaraan - guna menghindari bising dan polusi 
c. Berdekatan dengan alam sehingga dapat memanfaatkan sekitar tapak untuk proses penyembuhan

Lokasi tapak yang dipilih adalah Jagakarsa dimana daerah tersebut telah memenuhi syarat dalam kriteria pemilihan tapak

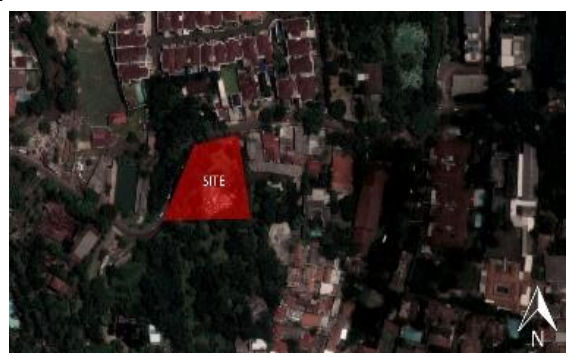

Gambar 1. Lokasi Tapak

Sumber: Google Maps, 2019

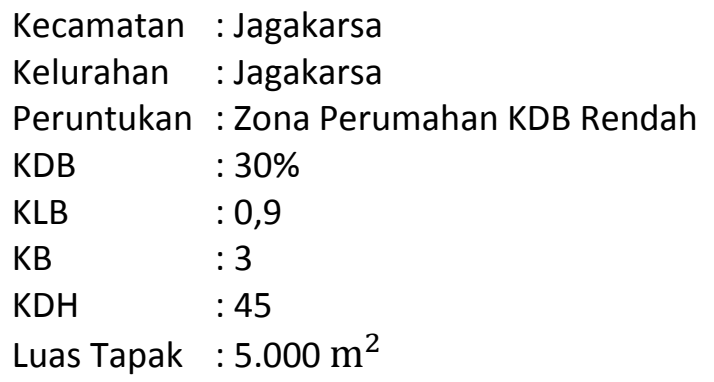

Tapak berada pada Jakarta Selatan mendekati daerah pinggiran Jakarta, karena kawasan di area tersebut masih banyak ruang terbuka hijau dan cocok dengan beberapa kriteria tapak. Walaupun tapak bukan berada di jalan utama, tetapi masih dilewati oleh angkutan umum. Selain itu, tapak berada di sekitar area terbuka hijau sehingga dapat memberikan pengudaraan alami dan view yang baik untuk tapak dan area ruang terbuka hijau dapat membantu proses penyembuhan penderita karena menurut Esther Sternberg dalam "Healing Space", tempat yang memberikan kebahagiaan dapat mempengaruhi kesehatan dan kebahagiaan itu adalah paradise dimana dapat dilihat bahwa paradise merupakan suasanasuasana alam. Site juga dekat dengan beberapa fasilitas kesehatan yang saling menunjang satu sama lain.

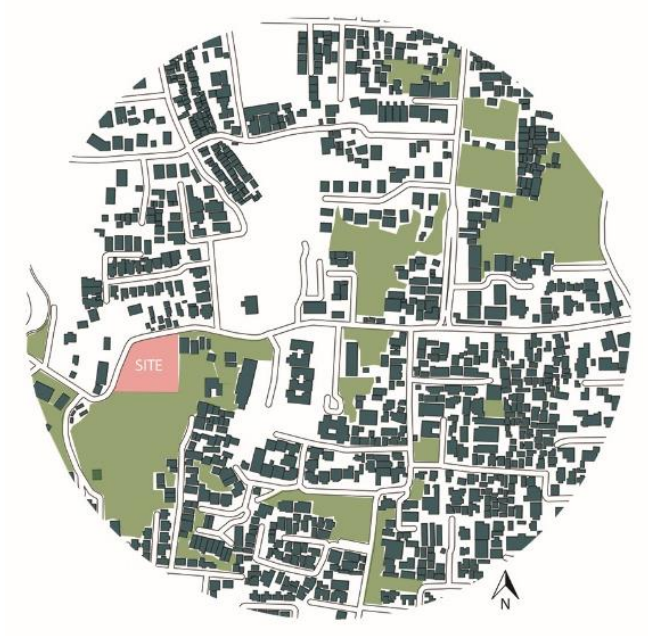

Gambar 2. Area Penghijauan

Sumber: Penulis, 2019 


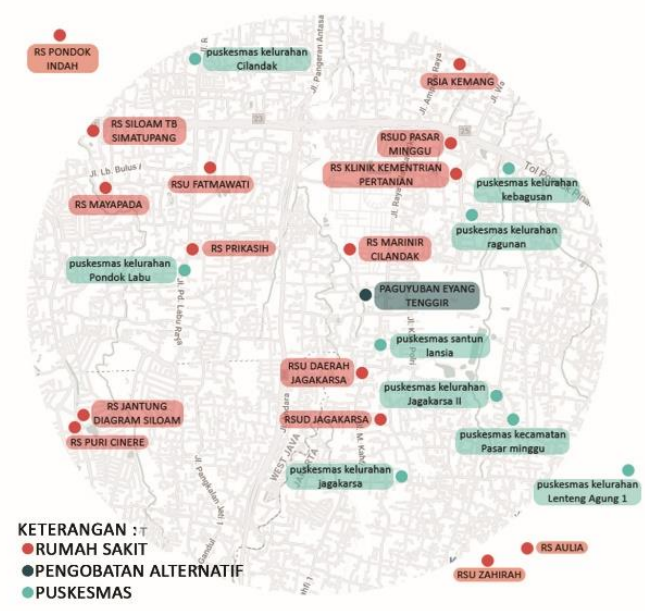

Gambar 3. Titik Fasilitas Kesehatan Sumber: Penulis, 2019

\section{Konsep}

Konsep yang digunakan pada perancangan ini adalah kembali ke alam dimana alam merupakan salah satu kunci utama dalam proses penyembuhan. Tidak lepas dari arsitektur, arsitektur memiliki peran penting karena semua aktivitas yang terjadi dalam proses penyembuhan dilakukan dalam ruang-ruang yang terbentuk berdasarkan fungsinya sehingga arsitektur memiliki 3 peran penting, yaitu memiliki hubungan dengan alam (menghubungkan alam ke dalam bangunan sehingga terdapatnya interaksi yang tercipta antara alam dengan kegiatan yang berada dalam bangunan), fisik (bentuk bangunan mendukung proses penyembuhan dimana menggunakan persepsi psikologis), dan sosial (terdapatnya interaksi yang nyaman baik di dalam maupun di luar).

Berdasarkan metode tersebut, desain program dilakukan berdasarkan 7 tahapan depresi dimana 7 tahapan tersebut adalah sebagai berikut:
a. Shock and denial
b. Pain and guilt
c. Anger and bargaining
d. Depression, reflection, and loneliness
e. The upward turn
f. Reconstruction and working through
g. Acceptance and hope

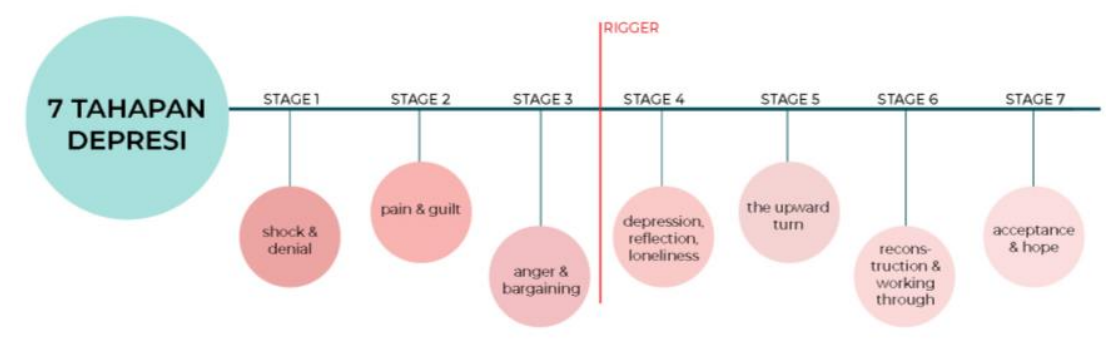

Gambar 4. Tujuh Tahapan Depresi

Sumber: Penulis, 2019

7 tahapan ini dijabarkan dalam bentuk arsitektur sehingga perancangan dapat ikut serta dalam proses penyembuhan. Stage $1-3$ merupakan tahap dimana tingkat depresi masih dikategori ringan sehingga membutuhkan open space, green space, dan aquascapes. Pada 
tahap ini, pendekatan pada alam secara tidak langsung dapat mengurangi tingkat stres yang diderita oleh penderita. Stage 4 dan 5 adalah tahapan dimana penderita sudah mencapai titik puncak depresi sehingga membutuhkan ruang yang closed space dan urban viewpoint. Pada tahap ini, penderita membutuhkan privasi yang tinggi akan tetapi tidak terlalu terisolasi dimana penderita dapat melihat lingkungan sekitar tapi sekitar tidak dapat melihat penderita. Hal tersebut terjadi akibat penderita masih malu akan stigma yang tertanam tentang depresi. Stage 6 dan 7 merupakan tahapan dimana penderita sudah menerima depresi yang diderita dan ingin mengetahui lebih dalam sehingga membutuhkan ruang informasi dan ruang komunitas. Ruang komunitas digunakan untuk mendukung proses pemulihan penderita dalam mendapatkan jati dirinya kembali dengan lingkungan yang positif dan menstimulasi kesehatan mental mereka sehingga ruang ini adalah wadah dimana para penderita dapat berkumpul dan saling berbagi pengalaman (sharing).

Hal tersebut dilakukan agar proses penyembuhan dapat dilakukan secara bertahap dan bentuk rancangan pun ikut serta membantu dalam proses penyembuhan pasien karena dalam pendekatan healing environment, rancangan harus dapat memenuhi dalam segi psikologis pasien. 7 tahapan depresi menjadi salah satu penerapan untuk gubahan massa dimana hasil bentuknya berupa pecahan-pecahan 7 tahapan depresi yang saling terhubung menjadi satukesatuan yang kokoh. Alur sirkulasi yang ada pada rancangan ini berbasiskan terhadap 7 depresi hingga pengunjung tidak dapat berhenti di tengah tahapan tersebut.

\section{Proses Gubahan Massa}

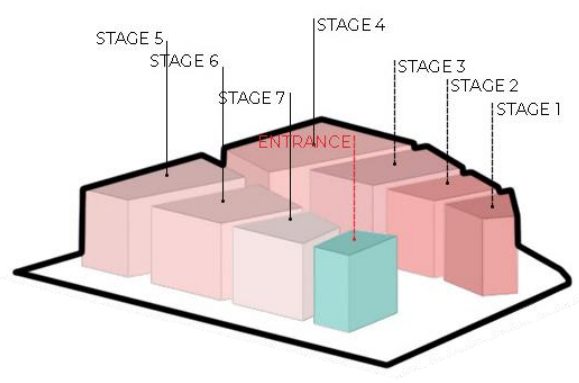

Gambar 5. Urutan 7 Tahapan Depresi dalam Proses Gubahan Massa Sumber: Penulis, 2019

Bangunan terbagi menjadi 7 bagian yang sesuai dengan 7 tahapan depresi dimana pengunjung dapat mengalami setiap tahapan secara berurutan

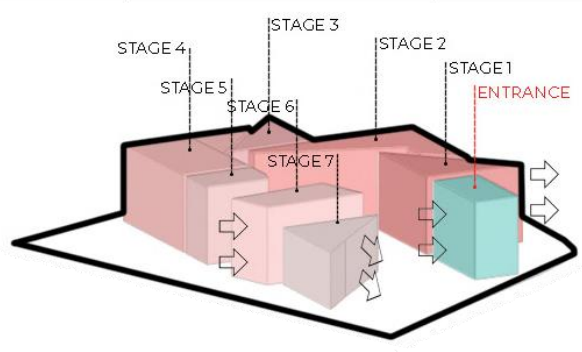

Gambar 6. Pembentukan Bangunan sesuai dengan 7 Tahapan Depresi Sumber: Penulis, 2019

Bangunan dibentuk sedemikian rupa dimana mencerminkan perjalanan penderita depresi yang berliku, bercabang, tertahan, dan banyaknya pilihan dari tahap awal menuju penyembuhan. 


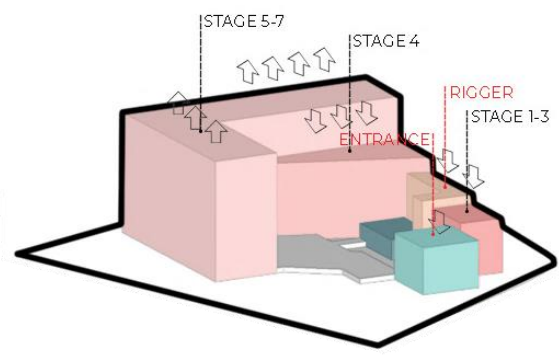

Gambar 7. Proses Permainan Ketinggian Bangunan Sumber: Penulis, 2019

Bentuk bangunan mengoptimalkan pandangan dan membuatnya lebih mudah diakses. Bangunannya dimainkan ketinggian dimana tahapan awal lebih rendah daripada tahapan akhir yang mencerminkan proses penyembuhan.

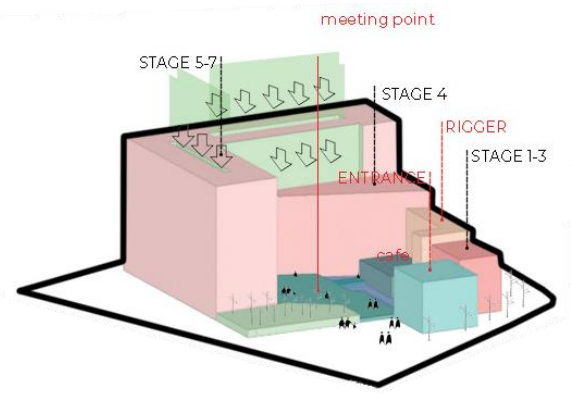

Gambar 8. Letak Void dan Meeting Point dalam Bangunan Sumber: Penulis, 2019

Terdapatnya beberapa meeting point baik dalam bangunan maupun luar bangunan guna untuk tempat berkumpulnya penderita dan pengunjung untuk berinteraksi atau sharing (berbagi) sehingga dapat mengubah stigma yang sudah tertanam mengenai kesehatan mental (depresi).

\section{Zoning}

Zonasi program ruang dibagi menjadi 2 zoning yaitu zonasi untuk rehabilitasi dan edukasi. Hal tersebut terbagi berdasarkan dari kebisingan dan privasi yang dibutuhkan pada saat aktivitas berlangsung. Semakin privasi aktivitas tersebut, maka sirkulasi menuju ruanganruangan tersebut semakin dibatasi. Diantara 2 zonasi tersebut terdapatnya meeting point dimana tidak adanya pembatas antara penderita dan masyarakat sehingga dapat bersosialisasi baik secara langsung maupun tidak langsung. Terdapatnya juga beberapa titik ruang komunal di dalam bangunan yang dapat digunakan juga untuk berinteraksi dan mempelajari lebih luas mengenai depresi dan cara menyikapinya. 


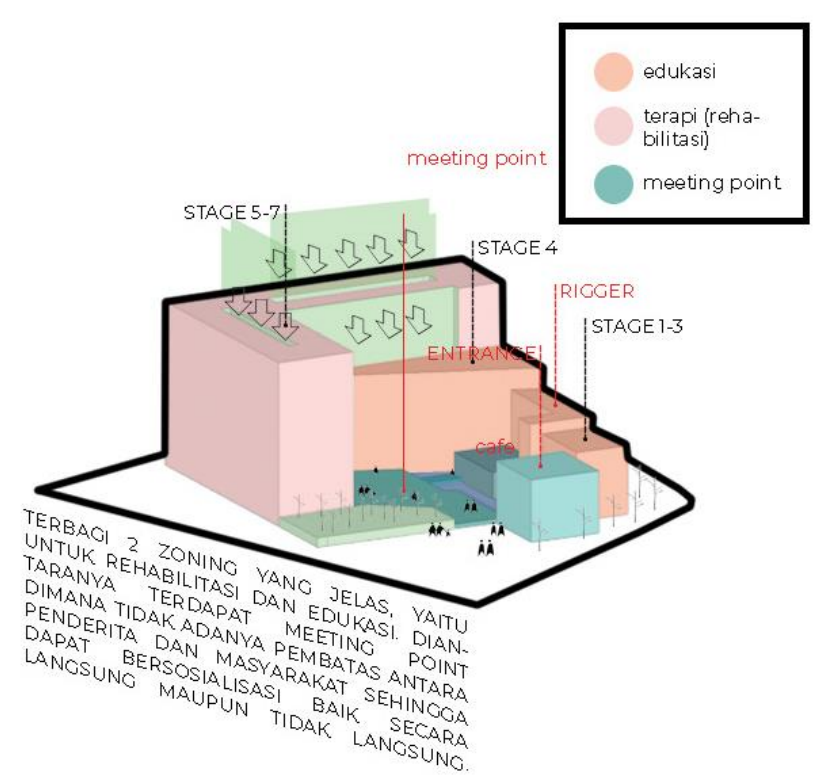

Gambar 9. Zoning

Sumber: Penulis, 2019

\section{Keunggulan Desain}

Pengudaraan, Pencahayaan, dan Material Alami

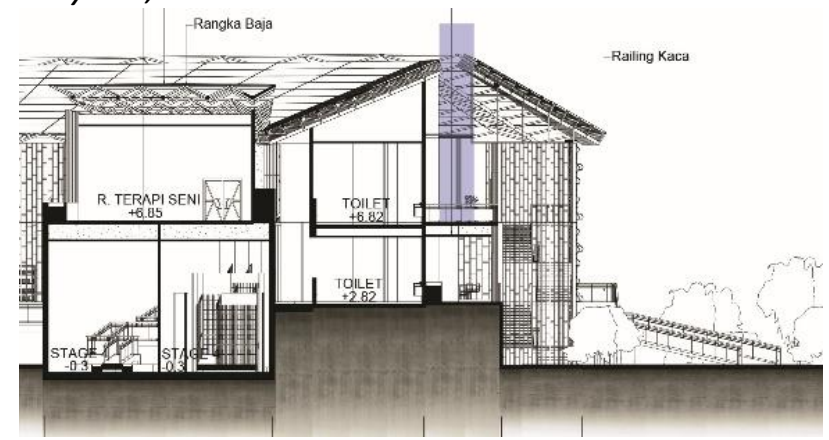

Gambar 10. Pengudaraan dan Pencahayaan Alami Sumber: Penulis, 2019

Pengudaraan dan pencahayaan alami sangatlah penting dalam proses penyembuhan, maka rancangan ini dimaksimalkan pencahayaan dan pengudaraan alami. Ventilasi silang diterapkan pada bangunan ini sehingga hampir seluruh ruangan tidak memerlukan AC (air conditioner) dan mendapatkan banyak cahaya matahari yang masuk ke dalam bangunan.

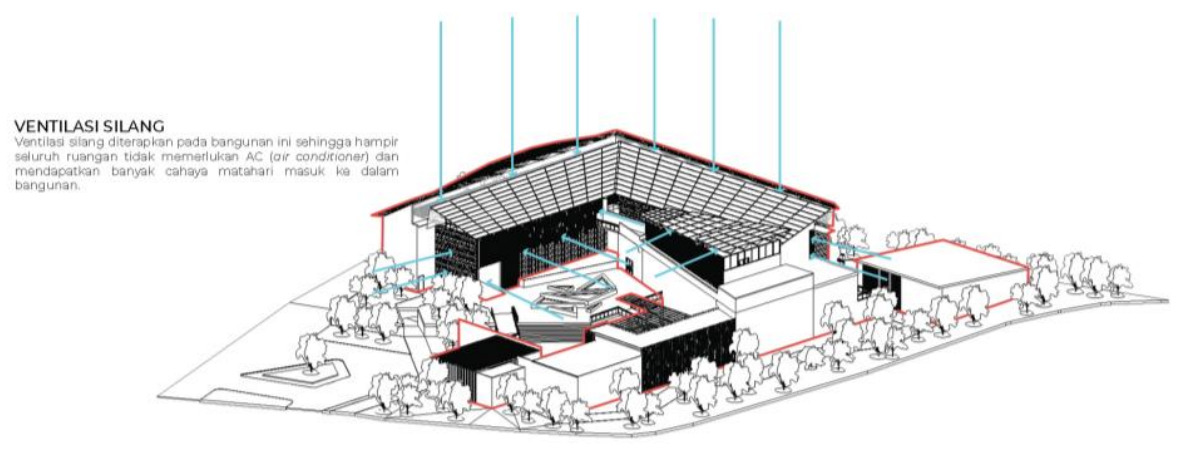

Gambar 11. Ventilasi Silang

Sumber: Penulis, 2019 


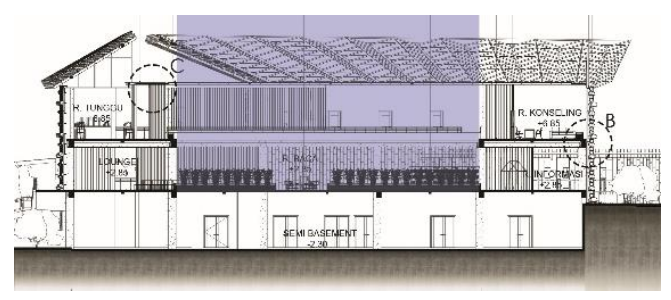

Gambar 12. Letak Void

Sumber: Penulis, 2019

Massa yang masif diberikan void dari atap hingga lantai dasar yang bertujuan agar pencahayaan dan pengudaraan alami masuk. Begitu pula dengan penggunaan material fasad yang ikut mendukung dalam proses penyembuhan. Kayu dapat memberikan suasana lebih hangat, nyaman, dan tenang. Kayu merupakan penggunaan material fasad yang paling utama dimana kayu dapat mengurangi stres dan depresi serta memiliki efek menenangkan dimana didasarkan pada pengalaman emosional positif yang disebabkan oleh kayu, seperti kedekatan dengan alam, kehangatan, kesederhanaan, dan efek relaksasi.

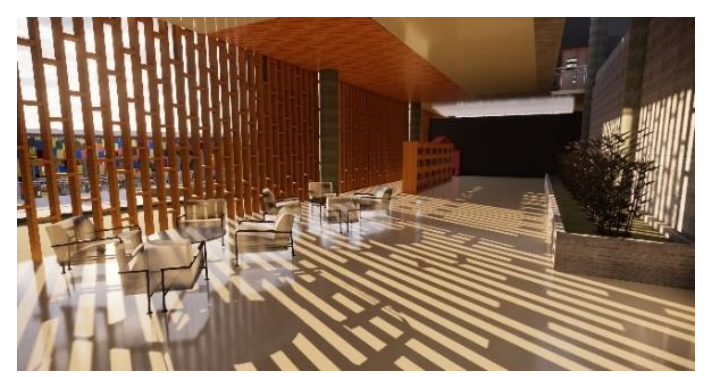

Gambar 13. Pencahayaan Alami dan Penggunaan Material Kayu Sumber: Penulis, 2019

\section{Pengalaman Multi-Sensorial}

Pengunjung akan disuguhkan dengan elemen pembentuk ruang (spasial) dan material yang memicu indera-indera manusia seperti auditori (kisi-kisi kayu), olfaktori (tanaman hias (terapi aromatik)), dan visual (kisi-kisi kayu).

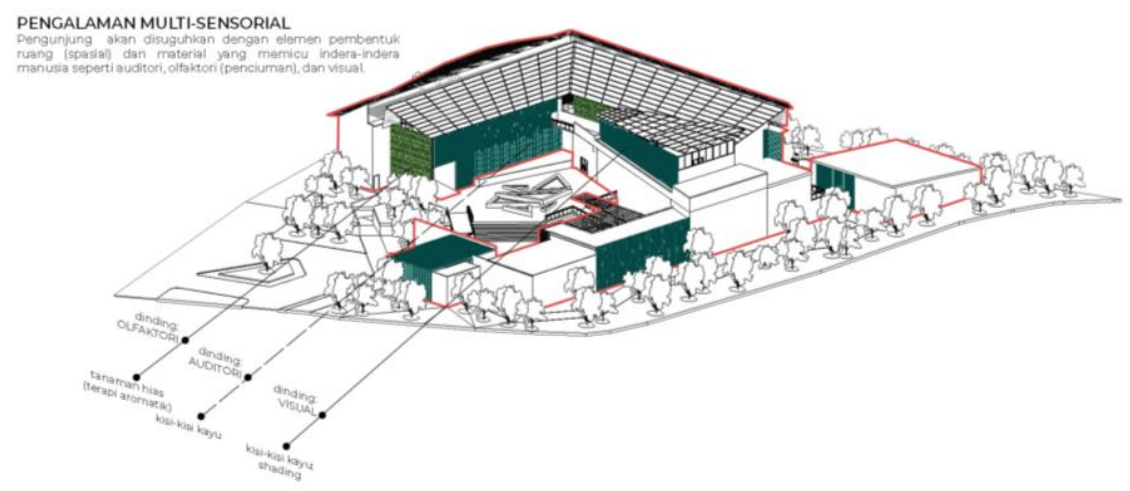

Gambar 14. Pengalaman Multi Sensorial Sumber: Penulis, 2019 


\section{Ruang Komunal}

Bentuk bangunan mengoptimalkan pandangan dan membuatnya lebih mudah diakses. Terdapatnya meeting point baik di luar maupun di dalam bangunan dimana para pengunjung dapat berinteraksi tanpa membeda-bedakan antara penderita dan masyarakat.

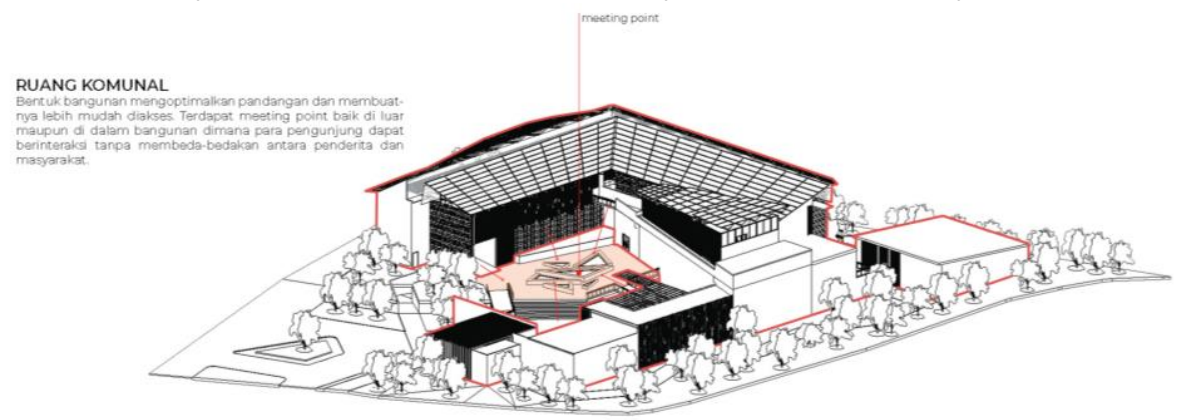

Gambar 15. Ruang Komunal Sumber: Penulis, 2019

\section{Echo Therapy}

Forest bathing merupakan salah satu metode terapi yang digunakan dimana pasien kembali ke alam. Metode ini digunakan dengan cara berjalan kaki di sekitar alam dan menikmati segala hal yang terdapat di dalamnya. Metode ini dapat menurunkan rasa stres dan dapat meningkatkan daya tahan tubuh. Selain itu, dimasukkannya alam ke dalam bangunan (terapi aromatik).

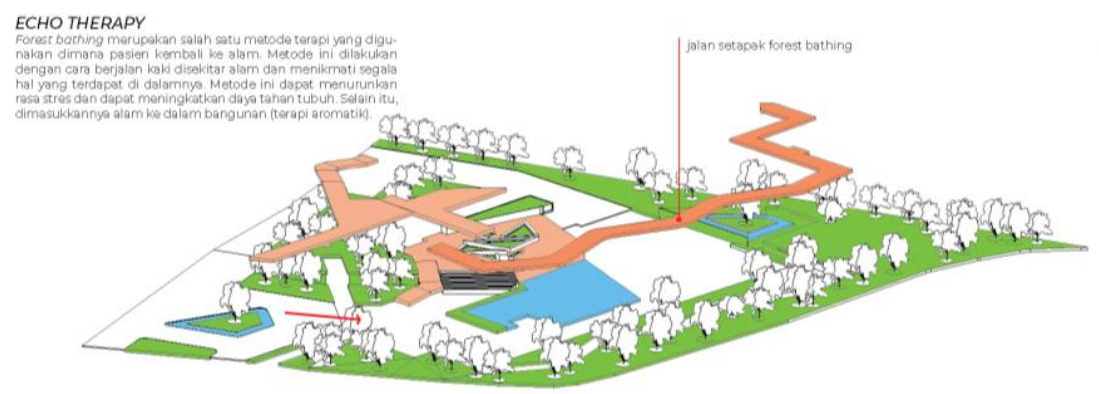

Gambar 16. Ruang Echo Therapy Sumber: Penulis, 2019

Ruang luar tidak lepas dari perancangan, maka dilibatkanlah ruang luar dimana pengunjung dapat jalan santai di sekeliling alam dan dapat bersosialisasi baik penderita dan pengunjung lainnya sehingga terwujudnya terapi support dimana terapi tersebut tidak membutuhkan ruang khusus dan aktivitas lainnya. Selama sosialisasi berlangsung, maka terapi support berjalan dengan sendirinya.

\section{KESIMPULAN DAN SARAN}

Penderita depresi setiap tahunnya meningkat sehingga depresi tidak boleh dianggap remeh. Akan tetapi, upaya penanganan di Indonesia masih jauh dari harapan. Tidak adanya wadah untuk penanganan secara bertahap dalam proses penyembuhan depresi ringan - sedang dimana tingkatan tersebut merupakan awal menuju depresi berat.

Arsitektur ikut serta dalam membantu program yang ada dalam proyek untuk proses penyembuhan. Aspek yang berperan adalah arsitektur dan psikologis. Arsitektur dapat mempengaruhi persepsi secara visual sehingga diterapkan dalam pembentukan bangunan. Dalam aspek psikologi dimana arsitektur dapat ikut membantu menurunkan tingkat stres dengan penggunaan material kayu. Dalam rancangan ini, memberikan wadah kepada para 
penderita dan pengunjung untuk mengetahui lebih lanjut mengenai depresi karena pengertian depresi di Indonesia masih terbilang salah sehingga menimbulkan stigma negatif.

Hasil studi ini masih diperlukannya penyempurnaan karena kurangnya referensi dan teori yang pasti tentang kebutuhan pengobatan depresi. Salah satunya adalah penggunaan material yang masih dalam konteks general.

\section{REFERENSI}

Alread, J. dan Leslie, T. (2007). Design Tech: Building Science for Architect. London: Elseiver, Linacre House, Jordan Hill, Oxford.

American Psychiatric Association. (2000). Diagnostic and Statistical Manual of Mental Disorders (Fourth Edition-Text Revision): DSM-IV-TR. Washington DC: American Psychiatric Association.

Gifford, R. (2007). Environmental Psychology: Principles and Practice (5 $5^{\text {th }}$ ed.). Colville, WA: Optimal Books.

Holahan, C. J. (1982). Environmentas Psychology. Random House, Inc.

Kaplan, H. I. (2010). IImu Kedokteran Jiwa Darurat. Jakarta: Widya Medika.

Knecht, M. L. (2010). Optimal Healing Environments. Healthy Communities by Design: Redlands and Loma Linda, CA.

Laurens, J. M. (2004). Arsitektur dan Perilaku Manusia. Jakarta: Grasindo

Rosenvald, T., Oei, T. P. S. \& Schmidt, M. (2007). Flight Your Dark Shadow: Managing Depression with Cognitive Behaviour Therapy (I. Saraswati, trans). Brisbane: Depression Managed.

Solomon, R. M. (2009). Customer Behaviour: An European Perspective. New Jersey: Financial Times Pretince Hall.

Express. (2012, December 4). Smell to Make You Well. Diambil kembali dari Express: https://www.express.co.uk/life-style/health/362320/Smells-to-make-you-well

Greeners.co. (2018, November 11). Stres? Hirup 5 Aroma Bunga Ini! Diambil kembali dari Greeners: https://www.greeners.co/gaya-hidup/stres-hirup-5-aroma-bunga-ini/

Katagaluh perantau. (2014). Perawatan pada Rehabilitasi Gangguan Jiwa. Diambil kembali dari Katagaluhperantau: http://katagaluhperantau.blogspot.com/2014/04/perawatanpada-rehabilitasi-gangguan.html

Pressreader. (2017). Menjadi Generasi Narsis Tahan Banting. Diambil kembali dari Pressreader: https://www.pressreader.com/indonesia/nova/20170109/281560880481397 
